\title{
Inovasi Pembelajaran Ilmu Falak Menggunakan CODACC Learning
}

\author{
Ahmad Fauzi \\ Sekolah Tinggi Agama Islam Wali Sembilan Semarang \\ ahmad_fauzy@ymail.com \\ IbnuHadjar \\ Guru Besar UIN Walisongo Semarang \\ ibnu_hadjar@walisongo.ac.id \\ Maesaroh \\ Universitas Muhamadiyah Yogyakarta \\ sarohdimyati@gmail.com
}

\begin{abstract}
ASTRONOMY LEARNING INNOVATIONS USING CODACC

LEARNING. Learning model innovation is needed to improve learning outcome. Nowadays, cognitive learning outcome of Astronomy is less satisfactory, it is caused by the incompatibility of learning models. The use of learning models is still conventional and not constructive. It produce passive learners and unable to build their own knowledge. Therefore, a constructive learning model in Astronomy is crucial. This research employs qualitative method with documentation technique by combining some sources of expert in the field constructivist learning models. The result of this study was to find an approprioriate learning model for Astronomy. The results reveal that Codacc Learning is a learning model intended to make learners that are able to develop their own understanding with discovery, active, cooperative, and contextual learning. The steps of implementing Codacc Learning are developed through some strategies.
\end{abstract}

Keywords: Astronomy; learning model; CODACC. 


\begin{abstract}
Abstrak
Inovasi model pembelajaran diperlukan untuk meningkatkan hasil pembelajaran. Hasil belajar kognitif ilmu Falak saat ini kurang memuaskan, salah satu penyebabnya adalah model pembelajaran yang kurang tepat. Saat ini, model pembelajaran masih bersifat konvensional dan tidak konstruktif, sehingga peserta didik menjadi pasif dan tidak mampu membangun pengetahuannya sendiri. Oleh karena itu, diperlukan sebuah model pembelajaran konstruktivistik yang dapat menjadikan peserta didik lebih aktif dan mampu membangun pemahamannya sendiri. Penelitian ini menggunakan metode kualitatitif dengan teknik dokumentasi bersumber dari dokumen buku, jurnal dan laporan penelitian yang berhubungan dengan model pembelajaran kontruktivistik. Hasilnya adalah untuk sebuah model pembelajaran yang tepat untuk ilmu Falak. Hasil penelitian menunjukkan bahwa Codacc Learning adalah model pembelajaran yang bertujuan membuat peserta didik mampu mengembangkan pemahamannya sendiri melalui discovery, active, cooperative, dan contextual learning. Langkahlangkah implementasi Codacc Learning dalam Ilmu Falak melalui berbagai macam strategi
\end{abstract}

Kata Kunci: Ilmu Falak; model pembelajaran; CODACC.

\title{
A. Pendahuluan
}

Pembelajaran yang efektif dan efisien perlu diterapkan pada semua bidang materi ilmu. Di dalam ilmu Falak juga diperlukan pembelajaran yang menjadikan ilmu Falak mudah dipahami. Terlebih ilmu Falak merupakan ilmu pengetahuan yang mempunyai andil besar dalam kehidupan, terutama bagi umat Islam. Hampir semua pelaksanaan ajaran agama Islam berhubungan dengan waktu, yang merupakan bagian dari kajian ilmu Falak. Misalnya ibadah yang berhubungan dengan waktu atau yang di kenal dengan ibadah muwaqqat seperti salat, puasa, zakat, haji dan lain sebagainya. Sedangkan manfaat yang lain adalah bahwa umat manusia dalam kehidupan sehari-hari tidak terlepas dari waktu dan penanggalan, baik pedagang, pegawai, nelayan, dan lain-lain. Penanggalan merupakan bagian dari kajian ilmu Falak dan ilmu Falak sampai saat ini masih sangat krusial dikaji di berbagai kalangan (Hambali 2011,6). 
Pembelajaran ilmu Falak saat ini terkesan sulit diajarkan di lembaga-lembaga pendidikan, termasuk juga di Perguruan Tinggi. Salah satu Perguruan Tinggi yang mengajarkan ilmu Falak adalah Fakultas Syariah dan Hukum UIN Walisongo, Semarang. Ilmu Falak terkenal ilmu yang rumit, susah dan sulit yang mengakibatkan kurangnya minat mahasiswa terhadap ilmu Falak. Terlebih kedekatan ilmu Falak terhadap matematika dalam perhitungan dan kesulitannya. Dalam hal mengajarkannya juga tidak mudah, karena materi yang kompleks, maka dibutuhkan kesabaran dan ketelatenan. Hal ini dibuktikan dengan hasil rekap nilai Ujian Akhir Semester (UAS) Ilmu Falak semester gasal tahun Ajaran 2017-2018 Fakultas Syariah dan Hukum Islam UIN Walisongo. Hasil pembelajaran ilmu Falak di salah satu jurusan di FSH kurang memuaskan. Sebab, mayoritas mahasiswa mengulang mata kuliah tersebut, yaitu sebanyak 25 dari 45 mahasiswa atau 56\% yang mengulang mata kuliah ilmu Falak dan 18 mahasiswa atau $40 \%$ yang lulus.

Terkait model pembelajaran yang digunakan, dewasa ini ternyata masih banyak model konvensional yang digunakan di Perguruan Tinggi. Pembelajaran yang berpusat pada pengajar, masih terkesan transfer of knowledge, sehingga pembelajaran tak ubahnya hanya seperti penyampaian materi kepada peserta didik tanpa adanya pemberian kesempatan untuk membangun pemahamannya sendiri. Peserta didik menjadi pasif, kurang aktif dan tidak begitu dilibatkan dalam pembelajaran. Pengajar lebih banyak menjelaskan dan teknik pembelajarannya kurang menantang kemampuan peserta didik. Pada hakikatnya, mengajar tidaklah hanya sekadar menyampaikan materi-materi pelajaran, tetapi juga perlu pemaknaan terhadap lingkungan belajar peserta didik. Pemaknaan pengajaran tersebut dapat diistilahkan sebagai pembelajaran. Proses belajar-mengajar seperti ini mengisyaratkan bahwa, pembelajaran haruslah berpusat pada peserta didik. Hal ini bertujuan untuk membina karakter, watak, mental, peradaban serta mutu peserta didik. Pemberdayaan semua potensi peserta didik dalam pembelajaran sangat diperlukan untuk menguasai kompetensi yang diharapkan (Hamruni 2009, 41).

Selain itu, proses interaksi dan komunikasi yang terjadi di dalam kelas antar pendidik dengan peserta didik, ataupun antar peserta didik harus berjalan dengan baik. Dalam hal ini, seseorang 
harus mampu memfungsikan dan mendayagunakan bahasa komunikasi di dalam konteks tertentu (Sari 2018, 164). Tidak jarang pendidik melakukan sesuatu yang dalam proses pembelajaran dapat menyebabkan suasana kelas menjadi tidak kondusif, diantaranya (1) tidak memiliki informasi mengenai kemampuan awal peserta didik, (2) tidak mengajari untuk berpikir kritis dan analitis, (3) tidak menginginkan feedback dari peserta didik, dan (4) berasumsi bahwa dirinya yang paling hebat dalam penguasaan materi pembelajaran (Hamruni 2009, 29-32).

Saat ini, pembelajaran ilmu Falak masih belum maksimal, pembelajarannya konvensional yang didasarkan pada filsafat positivisme, dan esensialisme. Hal tersebut berlawanan dengan pendekatan pembelajaran kontruktivisme. Sebab, dalam teori konstruktivisme diketahui bahwa peserta didik dapat mengembangkan intelektual dan minat mereka tanpa adanya instruksi formal (Burleson 2005, 436-451).

Dalam pandangan filsafat konstruktivisme, pengetahuan merupakan konstruksi atau konsepsi yang dibangun oleh seseorang yang sedang belajar. Pengetahuan tidak semata-mata terberikan (given), tetapi adalah sebuah proses yang panjang, tidak kilat dan yang perlu diusahakan. Pengetahuan yang ada dalam diri manusia yang dapat dipahami dengan baik sesungguhnya adalah merupakan sebuah perjalanan dalam melakukan kajian pemahaman dan analisis. Dalam pandangan konstruksivisme, pengetahuan merupakan sebuah proses dan kemudian pelan-pelan proses tersebut membentuk pengetahuan yang lebih lengkap dan benar. Menurut para konstruktivis, pengetahuan bisa dimiliki secara personal oleh peserta didik (Yamin 2015, 58-59). Oleh karena itu, diperlukan adanya inovasi dalam model, metode maupun strategi, agar pembelajaran lebih maksimal.

Inovasi penggunaan model pembelajaran perlu diperlukan dalam memperbaiki hasil belajar agar lebih maksimal, seperti penelitian Susilowati dkk tentang visualisasi spasial matematika dengan menggunakan inovasi strategi kognitif konflik yang dapat meningkatkan level hasil belajarnya lebih tinggi dari pada penggunaan pembelajaran ekspositori (konvensional) (Susilawati et al. n.d., 155). Penelitian Baddock juga menyebutkan bahwa dalam inovasi model pembelajaran demontrasi konflik terbukti dapat 
meningkatkan hasil pembelajaran (Baddock and Bucat 2008, 1115). Penelitian Beyhan juga mengusulkan model Fuzzy Function (EFF) yang mempunyai kontribusi memperkenalkan quasion nonlinear yang secara efektif dapat meningkatkan pembelajaran adaptif untuk kuadrat reklusif terkecil dalam sistem online nonlinier (Beyhan and Alci 2011, 168-182). Dalam penelitian-penelitian tersebut membuktikan bahwa suatu model pembelajaran itu diperlukan untuk mempermudah dalam proses pembelajaran. Terkhusus untuk materimateri keilmuan yang tidak mudah diajarkan. Ilmu Falak merupakan salah satu keilmuan kompleks, yang didalamnya terdapat hitunghitungan seperti matematika dan fisika yang memerlukan strategi pembelajaran tertentu agar lebih mudah difahami dan diajarkan dan dalam penelitian diatas belum ada sebuah model pembelajaran untuk ilmu Falak. Sehingga adanya suatu model pembelajaran yang khusus untuk ilmu Falak adalah sebuah keniscayaan.

Lebih lanjut bahwa banyak lulusan dari Fakultas Syariah dan Hukum yang disitu sudah mendapatkan mata kuliah ilmu Falak sebanyak 4 sks tetapi belum mampu mengaplikasikan ilmu Falak di masyarakat secara maksimal. Misalnya, dalam penentuan arah kiblat masih diperlukan tim khusus ahli Falak atau yang berasal dari jurusan murni ilmu Falak, yang dari lulusan Hukum Ekonomi Syariah (HES), Hukum Keluarga Islam (HKI), maupun Hukum Pidana dan Politik Islam kurang mampu mengaplikasikan ilmu Falak yang mereka dapat. Hal tersebut menunjukkan bahwa dalam pembelajaran mata kuliah ilmu Falak kurang efektif, dalam metode pembelajaran masih bersifat konvensional dan perlu model pembelajaran yang dapat mengatasi masalah itu. Untuk itu, perlu langkah khusus dalam metode pembelajaran ilmu Falak agar pembelajaran mata kuliah ilmu Falak di Fakultas Hukum dan Syariah semakin efektif.

Penggunaan strategi dan model pembelajaran tidak bisa dijauhkan dari kerangka filsafat yang mendasarinya. Pembelajaran dengan cara konvensional akan berdampak pada kurangnya efektivitas proses pembelajaran, serta nalar kritis dan kreatifitas peserta didik tidak terfasilitasi, sehingga menyebabkan rendahnya motivasi belajar dan minimnya hasil belajar. Sedangkan, model pembelajaran konstruktivistik dianggap dapat memberikan hasil yang maksimal dalam serangkaian proses pembelajaran, meningkatkan 
hasil belajar peserta didik (Anis Ma'tsumah 2014, 9-10). Jika dilihat dari pendekatan kognitif, proses belajar konstruktivistik secara konseptual menekankan pada pemberian makna oleh peserta didik melalui asimilasi dan akomodasi, bukan pada perolehan informasi yang hanya berlangsung searah dari eksternal ke internal diri peserta didik. Menurut pandangan model konstruktivistik, belajar adalah proses pembentukan pengetahuan yang dilakukan peserta didik secara langsung. Dalam artian, peserta didik harus terlibat aktif melakukan kegiatan, mampu menumbuhkan nalar berpikir kritis, mengembangkan konsep, serta memberi makna terhadap hal-hal yang sedang dipelajari (Budiningsih 2012, 58). Secara tidak langsung, pembelajaran merupakan inti dari proses pendidikan. Banyak hal yang menjadikan keberhasilan pembelajaran, salah satumya adalah pemilihan model pembelajaran yang tepat (Purwanto 2013, 45). Selanjutnya dalam mengembangkan model pembelajaran, para ahli menggunakan teori-teori yang bersumber dari psikologi, psikiatri, sosiologi, analisis sistem dan teori-teori yang lain yang berhubungan (Rusman 2014, 132).

Berdasarkan kajian diatas, penulis hendak menawarkan suatu model pembelajaran pengembangan yang baru yang diharapkan dapat meningkatkan kualitas hasil belajar ilmu Falak yang bernama Codacc Learning, yang sebelumnya belum ada model pembelajaran khusus untuk ilmu Falak. Codacc Learning ini diambil dari kata kontruksivistik (Contructivistic=Co), dan Discovery Learning (D), Active Learning (A), Cooperative Learning (C) dan Contextual Learning (C). Model Codacc ini dipandang sebagai model pembelajaran pengembangan baru yang merupakan kombinasi dari berbagai model-model pembelajaran.

Berdasarkan penjelasan di atas, penulis tertarik untuk mengetahui: (1) Bagaimanakah model pembelajaran Codacc Learning?, (2) Bagaimanakah langkah-langkah model pembelajaran Codacc Learning terhadap ilmu Falak?

\section{B. Pembahasan}

\section{Hakikat Model Pembelajaran}

Model pembelajaran bermakna sebagai suatu pola yang digunakan dalam pembelajaran. Model pembelajaran berisi berbagai 
teori yang digunakan dalam melaksanakan pembelajaran, khususnya teori yang berhubungan dengan strategi pembelajaran, metode pembelajaran, teknik pembelajaran dan pendekatan pembelajaran (B Uno 2009: 2). Menurut Joyce, model pembelajaran adalah suatu perencanaan atau suatu pola yang digunakan sebagai acuan dalam menyusun suatu pembelajaran di kelas, atau untuk menentukan perangkat-perangkat pembelajaran, seperti buku-buku, film, komputer, dan sebagainya. Kemudian Joice juga menyatakan bahwa setiap model pembelajaran merupakan pedoman untuk mendesain kegiatan-kegiatan pembelajaran yang membantu peserta didik, sehingga tujuan pembelajaran dapat tercapai (Trianto 2012: 22).

Dewasa ini, dalam pendidikan tinggi, sebagian besar mata kuliah masih berorientasi pada pedagogi instruksi tradisional dan metode penilaiannya. Misalnya, siswa sering diminta membaca buku teks, menghafal konsep, dan menjawab pertanyaan pilihan ganda dalam tes standar. Menurut taksonomi Bloom, pembelajaran semacam itu berada pada tingkat pengetahuan terendah. Sedangkan tujuan perguruan tinggi yaitu mempersiapkan peserta didik untuk karir masa depan di dunia nyata (Wang et al. 2013, 215). Dengan pembelajaran yang konstruktif diharapkan kegiatan belajar menjadi semangat, sangat ekspresif dan universal (Hernandez-Orallo 2000, 241). Dengan pendekatan konstruktif akan dapat memberikan manfaat yang berbeda terhadap tradisi pengajaran lama yang bersifat didaktik (Watson 2000, 137). Jadi, pendidik harus mempunyai cara dan strategi yang tepat untuk mewujudkan pembelajaran tersebut.

Kemp mengatakan bahwa strategi adalah suatu kegiatan pembelajaran yang harus dilaksanakan oleh pendidik dan peserta didik agar tujuan pembelajaran dapat dicapai secara efektif dan efisien. Senada dengan pemikiran Kemp, Dick dan Carey menyebutkan bahwa strategi pembelajaran adalah sebuah perangkat baik berupa materi maupun prosedur pembelajaran yang digunakan bersama-sama untuk mendapatkan hasil belajar para peserta didik. Pengimplementasian rencana pembelajaran yang telah dibuat supaya dapat dijalankan secara maksimal dan optimal, maka dibutuhkan suatu metode yang tepat untuk melaksanakan rencana tersebut. Dengan demikian, satu strategi pembelajaran yang menggunakan beberapa metode dapat diciptakan.(Rusman 2014, 132) Hal ini 
berarti bahwa metode pengajaran yang berbeda akan mempengaruhi cara kerja peserta didik (Toczek and Morge 2009, 326).

\section{Metode Penelitian}

Metode yang digunakan dalam penelitian ini adalah studi pustaka. Jenis penelitian ini adalah penelitian kualitatif. Dalam tulisan Lexi Moleong, Denzin dan Lincoln menyebutkan, bahwa penelitian kualitatif merupakan penelitian yang menggunakan latar belakang alamiah dengan tujuan menafsirkan fenomena-fenomena yang ada dan dilakukan dengan menggunakan berbagai metode tertentu. Dalam penelitian kualitatif, metode yang biasanya digunakan adalah wawancara, pengamatan dan pemanfaatan dokumen/ dokumentasi (Moleong 2010, 5). Dalam hal ini, penulis dalam pengumpulan data menggunakan teknik dokumentasi $(2005$, p. 82$)$. Data yang diambil bersumber dari dokumen, buku, jurnal dan laporan penelitian yang berhubungan dengan model pembelajaran kontruktivistik.

Pendekatan masalah yang digunakan penulis adalah dengan pendekatan metode deskriptif. Deskriptif yaitu data yang dikumpulkan adalah berupa kata-kata, kalimat-kalimat atau gambargambar. Hal ini disebabkan oleh adanya penerapan metode kualitatif. Selain itu, semua bahan yang telah dikumpulkan berkemungkinan akan menjadi kunci solusi terhadap apa yang telah di teliti (Moleong 2010, 11). Analisis yang digunakan sendiri adalah analisis kualitatif yang sebelumnya telah dilakukan kategorisasi dan pengelompokan data, seperti yang telah dijelaskan, data yang telah dihimpun akan dipilih sesuai dengan materi yang cocok dan tepat.

Fokus penelitian ini adalah untuk mencari model pembelajaran yang tepat untuk mata kuliah ilmu Falak agar dapat digunakan sebagai standarisasi model pembelajaran ilmu Falak yang ada, yaitu dengan model pembelajaran konstruktivistik yang diharapkan pembelajaran lebih efektif, efisien dan pembelajaran difokuskan pada student centered-learning. Sehingga peserta didik tidak menjadi obyek pembelajaran, tetapi menjadi subyek pembelajaran dan dapat mengembangkan pemahamannya sendiri. 


\section{Hasil Penelitian}

Kajian pustaka yang relevan dengan judul penelitian penulis adalah sebagai berikut: Penelitian Pada SMAN 3 dan SMAN 5 Kota Semarang tentang hasil belajar kognitif Pendidikan Agama Islam (PAI). Penelitian ini merupakan penelitian yang bertujuan menghasilkan model pembelajaran konstruktivistik yang dilaksanakan di SMAN 3 yang menerapkan pengelolaan moving class dan SMAN 5 yang pengelolaan kelasnya menggunakan sistem kelas tetap. Model pembelajaran yang dihasilkan adalah Codacc learning sebagai model pembelajaran yang digunakan untuk pelajaran PAI di SMA atau sederajat (Anis Ma'tsumah 2014, 147-153).

Persamaan dengan penelitian tersebut adalah sama-sama mencari model pembelajaran yang tepat berdasarkan model pembelajaran konstruktif. Sedangkan perbedaannya adalah penelitian Lift Anis Ma'tsumah yang dicari adalah model pembelajaran untuk pelajaran PAI pada siswa SMAN atau sederajat yang hasilnya yaitu model Conacc learning (Constructive, Active, Cooperative dan Contextual), sedangkan penelitian penulis adalah untuk mahasiswa perguruan tinggi dengan mata kuliah ilmu Falak. Ada pengembangan model dalam penelitian penulis yaitu Discovery Learning, karena dalam pembelajaran ilmu Falak, selain adanya pemahaman, kerjasama, dan praktek juga ada hitung-hitungan sehingga harus ada pengembangan model pembelajaran.

\section{a. Teori yang Mendasari Codacc Learning}

1) Teori konstruktivistik John Dewey

Teori konstruktivistik ini berpijak pada sebuah konsepsi bahwa siswa yang menghendaki sebuah informasi harus mampu menemukan dan mentransformasikan sendiri informasi tersebut. Berdasar pada hal ini, pembelajaran harus dikembangkan menjadi sebuah upaya untuk mengkonstruksi pengetahuan, bukan hanya menerimanya begitu saja. Oleh karena itu, landasan berpikir konstruktivisme sedikit berbeda dengan faham kaum objektivitas yang cenderung menekankan hasil pembelajaran. Sedangkan dalam teori konstruktivisme, strategi untuk memperoleh lebih utama dari pada seberapa banyak siswa mendapatkan dan mengingat pengetahuan (Sagala 2012, 88). 
Gagasan utama dari teori konstruktivistik yaitu memandang manusia sebagai siswa yang aktif dan mampu mengembangkan sendiri pengetahuan yang dibutuhkan. Siswa harus mengkonstruk pemahaman-pemahamannya secara mandiri untuk memahami materi dengan baik. Sedangkan guru harus mampu memfasilitasi terbentuknya suasana pembelajaran yang mendukung terlibatnya siswa dalam pembelajaran melalui pengolahan materi dan interaksi sosial. Jadi guru tidak diperbolehkan mengajar secara konvensional (Palmer et al., n.d., 2012, 323-324). Sebab, guru dapat mengantarkan peserta didik menuju kepemahaman lebih tinggi dengan cara memberinya anak tangga dan ia harus memanjatnya sendiri (Trianto $2012,28)$. Oleh karena itu, guru wajib mempunyai strategi yang tepat untuk mewujudkan pembelajaran tersebut. Jadi, pada dasarnya teori konstruktivistik yang besumber dari teori progresivisme John Dewey menyatakan bahwa pengetahuan itu dibentuk sendiri oleh individu. Sehingga pengetahuan yang dibangun berupa ide dalam proses pendidikan nantinya digunakan sebagai persiapan masa depan yang jauh (Dewey 2001, 85).

2) Teori Perkembangan Kognitif Jean Piaget

Jean Piaget menulis 11 buku tentang epistemologi konstruktivistik. Piaget menjelaskan bahwa pendidikan tergantung pada epistemologinya. Keduanya memiliki kaitan dalam hal pengetahuan dan perkembangan sebagai fakta-fakta yang normatif. Menurut Piaget, epistemologi yang memadai harus memaparkan mekanisme yang memunculkan adanya pengetahuan baru, yakni perkembangan yang disebut ekuilibrasi (equilibration). Teori perkembangan Piaget mewakili teori kontruktivistik yang terkenal dengan nama Piaget Contruktivism Cognitif yang memandang bahwa seorang anak terlibat aktif dalam membentuk dan membangun sistem pemahamannya (Palmer 2015, 81).

Uraian Piaget tentang proses belajar (ekuilibrasi) mempunyai dua prinsip penting bagi pendidikan. Pertama, bahwa kreatifitas itu penting, sebab setiap pemikiran manusia yang digunakan dengan baik akan berpotensi untuk maju. Tiap individu diarahkan untuk berpikir dan memikirkan kembali tentang sistem dan konsep-konsep secara kolektif. Pikiran yang hidup (Living mind) adalah pikiran yang bekerja dengan kapasitas tertentu untuk membuat penilaian lebih 
baik. Prinsip ini mengarah pada prinsip kedua bahwa pengajaran bisa efektif dengan sendirinya. Apa yang diperlukan adalah desain kreatif untuk menyusun tugas-tugas belajar yang secara normatif memberdayakan, bukan yang secara kausal melemahkan (Palmer 2015, 86).

3) Teori Multiple Intelligences Howard Gardner

Gardner percaya bahwa misi pendidikan adalah pengembangan pemahaman. Pemahaman yang mendalam harus menjadi tujuan dan landasan utama dalam bidang pendidikan. Gardner menjelaskan bahwa pemahaman ditandai dengan tindakan, dimana anak didik mendapatkan pengetahuan sedikit demi sedikit dalam suatu lingkungan dan mengaplikasikannya pada lingkungan atau permasalahan yang tidak mereka kenali. Hal ini dimaksudkan supaya tujuan tadi tercapai, maka para pendidik harus mengutamakan kedalaman dari pada keluasan. Peserta didik harus diberi kesempatan yang luas untuk memahami suatu topik. Gardner menyatakan bahwa cara untuk mengembangkan pemahaman peserta didik dapat dilakukan dengan memberinya kesempatan memahami suatu topik secara mendalam dan mengekspresikannya melalui beragam cara yang melibatkan kecerdasan (Palmer 2015, 523).

Teori-teori yang disebutkan diatas secara substansi mendasari dan mendukung model pembelajarn Codacc Learning. Penulis tidak mengambil salah satu dari teori-teori pakar diatas, namun secara substansial mengakomodir teori-teori diatas.

\section{b. Dasar Pertimbangan Pemilihan Model}

Sebelum memilih model pembelajaran yang akan dipakai, beberapa hal yang harus dijadikan pertimbangan oleh pendidik dalam memilihnya adalah:(Rusman 2014, 133-134)

1. Pertimbangan berkaitan dengan tujuan yang akan dicapai.

2. Pertimbangan yang berhubungan dengan bahan atau materi pembelajaran.

3. Pertimbangan dari arah peserta didik.

4. Pertimbangan lain yang bersifat non teknis.

c. Ciri-ciri Model Pembelajaran Codacc

Model Pembelajaran Codacc mempunyai ciri-ciri sebagai berikut:(Rusman 2014, 136) 
1. Berlandaskan pada teori pendidikan dan teori ilmu Falak dari para ahli.

2. Mempunyai prinsip dan tujuan pendidikan ilmu Falak.

3. Sebagai pedoman dan arah untuk memperbaiki kegiatan belajar mengajar di kelas ilmu Falak.

4. Memiliki bagian-bagian model yang disebut dengan: urutan langkah-langkah pembelajaran, terdapat prinsip reaksi, terdapat sistem sosial, dan sistem pendukung yang semuanya disesuaikan dengan ilmu Falak.

5. Mempunyai dampak sebagai akibat terapan model pembelajaran Codacc.

6. Mempersiapan bahan mengajar (desain intruksional) dengan menggunakan panduan model pembelajaran Codacc.

\section{d. Model Codacc Learning}

Model-model pembelajaran disusun berlandaskan berbagai macam prinsip dan teori pengetahuan. Para ahli merancang model pembelajaran berdasarkan berbagai prinsip dan teori, seperti prinsip pendidikan, teori psikologis, teori sosiologis, teori analisis sistem, atau teori-teori lain yang mendukung. Joyce dan Weil menganalisa modelmodel pembelajaran berdasarkan teori belajar yang dikelompokkan menjadi beberapa model pembelajaran, sebagai berikut (Rusman 2014, 132-133):

\section{1) Discovery Learning (Pembelajaran Penemuan)}

Model pembelajaran penemuan (discovery learning) merupakan suatu model pembelajaran yang memfasilitasi siswa dalam mengembangkan nalar kritis melalui penemuan dan pembentukan pemahamannya secara mandiri, serta memberi kesempatan padanya untuk terlibat aktif di dalam pembelajaran, sehingga belajar Matematika menjadi lebih bermakna, mudah dipahami dan disimpan dengan baik oleh memori siswa. Discovery learning $(D L)$ ini merupakan model pembelajaran yang menekankan pada kemandirian siswa dalam mengkonstruksi pemahaman untuk menemukan sebuah konsep, bukan hanya menyajikan konsep dalam bentuk jadi kepada siswa (Supraptinah and Subanti 2015, 49).

Discovery Learning merupakan suatu model intruksional kognitif yang sangat berpengaruh yang diprakarsai oleh Jerome Bruner. Model pembelajaran ini berbasis pada penemuan yang 
dilakukan secara aktif oleh siswa melalui konstruksi pemahaman, dan secara sendirinya memberikan hasil yang maksimal. Siswa secara mandiri berusaha mencari pemecahan masalah dan konsepsi pengetahuan, sehingga benar-benar menghasilkan pengetahuan yang bermakna (Trianto 2012, 38). Model Discovery Learning diantaranya menggunakan metode diskusi, dan pemberian tugas. Sedangkan karakteristik model Discovery Learning, yaitu: (Christine 2009, 29)

a. Merumuskan suatu masalah untuk dipecahkan peserta didik.

b. Menyiapkan jawaban sementara dari masalah tersebut.

c. Peserta didik berusaha mencari dan menemukan informasi, data, fakta yang diperlukan sebagai bahan untuk menjawab hipotesis.

d. Menarik kesimpulan atau jawaban dari masalah.

e. Menerapkan generalisasi pada situasi baru.

2) Active Learning (Pembelajaran Aktif)

Peserta didik adalah individu yang memiliki identitas insani sebagai subyek berkesadaran, sehingga perlu dibela lewat sistem dan model pendidikan yang berciri bebas dan egaliter. Hal tersebut hanya dapat dicapai melalui proses pendidikan yang membebaskan dan metode pembelajaran dengan aksi dialogal. Oleh karena itu, peserta didik seharusnya diperlakukan dengan sangat hati-hati. Teori kognitif/konstruktivistik cenderung menekankan bahwa belajar ditentukan oleh adanya karsa individu. Penataan kondisi bukanlah penyebab terbentuknya belajar, tetapi hanya sekadar memudahkan belajar, keaktifan peserta didik menjadi unsur yang penting dalam upaya menentukan kesuksesan belajarnya. Aktivitas belajar mandiri merupakan jaminan untuk mencapai hasil kesuksesan yang sejati (Budiningsih 2012, 5).

Pembelajaran aktif adalah pendekatan pembelajaran yang memposisikan siswa untuk berpartisipasi aktif dalam mengakses berbagai macam informasi dan pengetahuan yang dikaji di dalam ruang kelas, sehingga siswa memperoleh pengalaman yang dapat meningkatkan pemahaman keilmuan dan kompetensinya (Rusman 2014, 324). Pembelajaran aktif merupakan metode pengajaran yang melibatkan siswa secara aktif; sedangkan pembelajaran kooperatif merupakan salah satu variasi pembelajaran aktif (Keyser 2000, 35). 
Untuk efektifitas metode ini, di ruang kelas merupakan hal yang tepat dalam pengaplikasian pembelajaran aktif maupun kooperatif.

Lebih dari itu, pembelajaran aktif akan memungkinkan peserta didik dalam mengembangkan kemampuan berfikir tingkat tinggi seperti dalam menganalisis dan mensintesis, serta melakukan penilaian terhadap berbagai macam peristiwa belajar dan menerapkannya dalam kehidupan sehari-hari. Pembelajaran aktif memliki persamaan dengan model pembelajaran self discovery learning, yakni pembelajaran yang dilakukan oleh peserta didik untuk menemukan kesimpulannya sendiri sehingga dapat dijadikan sebagai nilai dan esensi baru yang dapat diimplementasikan dalam kehidupan nyata.

Dalam pembelajaran aktif, pendidik memainkan peran sebagai seorang fasilitator yang memberikan kemudahan belajar kepada peserta didik dan mengelola jalannya proses pembelajaran. Sedangkan, peserta didik memegang peran penting dalam proses pembelajaran dengan terlibat secara aktif dalam berbagai macam kegiatan di dalam kelas (Rusman 2014, 324). Model pembelajaran menggunakan metode pembelajaran aktif disesuaikan dengan kebutuhan peserta didik, pembelajaran aktif yang sesuai dengan kurikulum, dan pembelajaran aktif dalam seni. Adapun karakteristik model pembelajaran Active Learning adalah:

a. Menciptakan suasana yang mengalir

b. Pembelajaran aktif dalam seni

c. Pembelajaran aktif dimanapun.

\section{3) Cooperative Learning (Pembelajaran Kooperatif)}

Menurut Soejadi, teori yang menjadi landasan pembelajaran kooperatif adalah teori dari konstruktivisme. Pada dasarnya, teori pembelajaran konstruktivisme adalah pendekatan yang menekankan kemandirian peserta didik dalam menemukan dan mentransformasi informasi yang kompleks, memeriksa informasi tersebut sesuai dengan aturan yang ada, dan melakukan perbaikan jika diperlukan (Rusman 2014, 132-133). Istilah cooperative learning (CL) mengacu pada siswa yang bekerja dalam tim dalam tugas atau proyek dalam kondisi dimana kriteria tertentu terpenuhi, termasuk anggota tim bertanggung jawab terhadap dirinya sendiri atas isi lengkap dari tugas atau proyek. 
Menurut Slavin, pembelajaran kooperatif menjadikan peserta didik agar mampu berinteraksi secara aktif, kreatif dan positif dalam kelompok. Hal ini memungkinkan terjadinya pertukaran ide dan pemeriksaan ide sendiri dalam suasana yang tidak terancam, sesuai dengan falsafah konstruksivisme. Dengan demikian, pendidikan harus mampu mengkondisikan dan memberikan dorongan supaya mampu mengoptimalkan dan membangkitkan potensi peserta didik, menumbuhkan aktivitas, serta daya cipta, sehingga dapat menjamin adanya dinamika di dalam proses belajar mengajar. Teori konstruksivisme itu lebih memprioritaskan pada pembelajaran peserta didik yang dihadapkan dengan masalah-masalah kompleks untuk ditemukan solusinya, selanjutnya mencari bagian-bagian yang lebih mudah dan sederhana serta memunculkan ketrampilan yang diharapkan. Model pembelajaran ini didasarkan teori belajar konstruktivisme yang berasal dari gagasan Piaget dan Vigotsky. Berdasarkan penelitian piaget yang pertama, dijelaskan bahwa pengetahuan itu dikonstruk di dalam pikiran anak (Rusman 2014, 201). Kooperatif atau kerja sama dapat ditemukan di berbagai tempat di dunia nyata, mulai dari sistem kehidupan hingga sistem ekonomi dan sosial. Namun, memahami kemunculan dan ketekunan kerja sama antar individu yang egois masih menjadi salah satu permasalahan yang fundamental (Zhang et al. 2010, 389).

Pembelajaran kooperatif menjadi lebih disukai oleh para ahli pendidikan karena bisa berfungsi sebagai sarana untuk menggabungkan metodologi pembelajaran aktif lainnya yang dampaknya menjadi lebih besar pada lingkungan kelas (Sand-Jecklin 2007, 475). Dan salah satu keutamaan pembelajaran kooperatif adalah peserta didik akan belajar lebih banyak dan lebih lama dalam mempertahankan pengetahuan (Keyser 2000, 36).

Pembelajaran ini berasal dari pandangan bahwa peserta didik akan lebih mudah menemukan, memecahkan masalah dan memahami konsep yang sulit jika mereka saling berdiskusi dengan teman-temannya. Peserta didik secara rutin bekerja saling membantu menyelesaikan masalah-masalah yang kompleks secara berkelompok. Jadi, aspek utama yang menjadi ciri khas dalam pembelajaran kooperatif adalah hakikat sosial dan penggunaan teman sejawat dalam pembelajaran (Trianto 2012, 56). Diantara contoh model 
Pembelajaran Cooperative Learning adalah STAD, Jigsaw, Investigasi kelompok (Teams Games Tournaments atau TGT), pendekatan struktural yang meliputi Think Pair Share (TPS) dan Numbered Head Together (NHT) (Trianto 2012, 67). Menurut Slavin, karakteristik model pembelajaran Cooperative Learning berbeda dalam banyak hal, tetapi dapat dikategorikan sesuai dengan sifat-sifat berikut: (Trianto 2012, 63)
a. Tujuan kelompok
b. Tanggung jawab individual
c. Kesempatan yang sama untuk meraih sukses
d. Kompetisi kelompok
e. Spesialisasi tugas
f. Adaptasi sesuai kebutuhan individu

4) Contextual Learning (Pembelajaran Kontekstual)

Pembelajaran kontekstual (contextual teaching and learning) merupakan konsep yang dapat membantu pendidik untuk menghubungkan materi yang akan diajarkan dengan kondisi dunia nyata peserta didik, dan mendorongnya membuat keterkaitan antara pengetahuan yang dimilikinya dengan aplikasinya dalam kehidupan sehari-hari.

Untuk memperkuat pengalaman belajar aplikatif bagi peserta didik, diperlukan pembelajaran yang menekankan pada pemberian kesempatan pada peserta didik untuk melakukan, mencoba dan mengalami sendiri dan bahkan sekadar menjadi pendengar yang pasif sebagaimana menerima terhadap semua informasi yang dipaparkan oleh pengajar. Oleh karena itu, melalui pembelajaran kontekstual, mengajar bukanlah transformasi pengetahuan dari pendidik kepada peserta didik melalui hafalan konsep-konsep yang sepertinya jauh dari kondisi kehidupan nyata, tetapi lebih ditekankan pada usaha untuk memfasilitasi peserta didik untuk mencari kemampuan supaya memiliki kemampuan hidup dari hal-hal yang telah dipelajarinya. Dengan demikian, pembelajaran akan lebih bernilai dan bermakna, lembaga pendidikan akan lebih dekat dengan lingkungan masyarakat (bukan dilihat dari segi fisik), tetapi secara fungsional materi yang dipelajari di lembaga pendidikan senantiasa bersinggungan dengan situasi, keadaan dan permasalahan kehidupan yang terjadi di lingkungan sekitar (keluarga dan masyarakat) (Rusman 2014, 189). 
Dewasa ini, ada harapan bahwa kurikulum yang dibuat memiliki tingkat daya saing, pengetahuan yang mendasar dan luas. Maka Contextual Learning merupakan pendekatan yang tepat untuk kembali berfikir bahwa peserta didik akan belajar lebih baik secara alamiah. Pembelajaran akan lebih bermakna jika peserta didik mengalami secara langsung hal-hal yang dipelajarinya, bukan cuma mengetahui. Artinya, dengan pengalaman maka akan membekas dan lebih teringat dalam memori peserta didik, dari pada mengetahui. Sebab, mengetahui itu bisa dibuktikan dengan praktek atau juga bisa dibuktikan dengan teori. Akan tetapi, jika mengalaminya, maka jelas seorang peserta didikmelihat, praktik, dan mengenalnya.

Pembelajaran yang mengutamakan pada penguasaan materi memang terbukti berhasil dalam proses mengingat, tetapi hasil tersebut tidak membekas, yang akhirnya berujung pada minimnya kemampuan dalam memecahkan masalah (Suranto 2009, 41). Pembelajaran kontekstual ini berbeda dengan pembelajaran lainnya dalam beberapa hal, seperti peserta didik harus menemukan hubungan penuh makna antara ide-ide abstrak dengan aplikasi praktis dalam konteks dunia nyata. Peserta didik harus bisa menginternalisasi konsep dan pemahaman melalui penemuan, penguatan, dan keterhubungan. Pembelajaran kontekstual juga menghendaki kerja dalam sebuah tim, baik di kelas, laboratorium, tempat bekerja maupun lapangan. Pembelajaran kontekstual cenderung menuntut pengajar untuk mendesain lingkungan tempat belajar yang merupakan gabungan beberapa bentuk pengalaman menarik untuk mencapai hasil yang diinginkan (Komalasari 2011,6).

Model pembelajaran Contextual Learning dapat menggunakan penerapan tujuh komponen yaitu: konstruktivisme, inkuiri, bertanya (questioning), pemodelan (modelling), masyarakat belajar (learning community), refleksi (reflection), dan penilaian sebenarnya (authentic assessment). Adapun karakteristik model pembelajaran Contextual Learning yang membedakan dengan model pembelajaran lainnya yaitu: (Trianto 2012, 104-110)

a. Adanya Kerja sama

b. Saling menunjang satu sama lain

c. Membuat pembelajaran menyenangkan, mengasyikkan, bergairah 
d. Tidak membosankan bagi peserta didik

e. Belajar menjadi bergairah

f. Pembelajaran menjadi terintegrasi

g. Menggunakan berbagai sumber sehingga peserta didik menjadi aktif.

\section{e. Langkah-Langkah Codacc Learning dalam Ilmu Falak}

Langkah-langkah penerapan codacc Learning pada ilmu Falak mengacu pada model discovery learning, active learning Mell Silbermen, dan cooperative learning Slavin, maka strategi yang dapat diterapkan dalam model codacc Learning adalah The Power Of Two, Information Search, Jigsaw, Debate Active, Listening Team, Modelling the way, Gallery Walk, Group to Group Exchange, Small Group Discussion, Billboard ranking, True Or False, dan lain sebagainya (Sibermen 2007, 143-236). Pemilihan strategi-strategi tersebut disesuaikan dengan berbagai jenis materi yang akan diajarkan.

Untuk desain sistem model pembelajaran konstruktivistik dijelaskan dalam tabel di berikut ini:

Tabel 1. Desain sistem model pembelajaran kontruktivistik dengan Codacc Learning

\begin{tabular}{|c|c|c|}
\hline No. & Komponen Desain & Kegiatan Pembelajaran \\
\hline 1. & Situasi & $\begin{array}{l}\text { Menyampaikan tujuan dilaksanakannya aktivitas } \\
\text { pembelajaran. } \\
\text { Menyampaikan tugas-tugas kepada peserta didik } \\
\text { yang perlu diselesaikan agar memiliki makna } \\
\text { pengalaman belajar. }\end{array}$ \\
\hline 2. & Pengelompokkan & $\begin{array}{l}\text { Mengelompokkan peserta didik (baik acak } \\
\text { maupun kriteria). } \\
\text { Memberikan kesempatan kepada peserta didik } \\
\text { agar melakukan interaksi kepada teman yang lain. }\end{array}$ \\
\hline 3. & Pengaitan & $\begin{array}{l}\text { Pendidik menghubungkan pengetahuan yang } \\
\text { telah dimiliki peserta didik dengan pengetahuan } \\
\text { baru } \\
\text { Dilakukan dengan berbagai bentuk seperti diskusi, } \\
\text { pemecahan masalah, kerja sama dll. }\end{array}$ \\
\hline
\end{tabular}


4. Pertanyaan

Pendidik mengajukan beberapa pertanyaan yang terkait.

Dari pertanyaan tersebut, peserta didik memunculkan gagasan-gagasannya sendiri dan membangun pengetahuannya.

5. Eksibisi

Memberikan kesempatan peserta didik menunjukkan hasil belajarnya setelah proses pembelajaran

Dilakukan dengan presentasi atau praktek langsung

6. Refleksi Memberikan kesempatan kepada pendidik dan peserta didik untuk mengemukakan pengalamannya sertalah proses pembelajaran.

Refleksi juga memberikan kepada peserta didik untuk berfikir

Sumber: Ma'shumah, 2014: 67-68

\section{Simpulan dan Saran}

Berdasarkan uraian dan analisis hasil penelitian, maka dapat disimpulkan bahwa Model pembelajaran Codacc Learning merupakan suatu pembelajaran kontruktivistik yang mempunyai tujuan untuk: (a) membantu peserta didik membangun pemahamannya sendiri, khususnya pada bidang ilmu Falak dengan cara memberi kesempatan peserta didik untuk menemukan permasalahan-permasalahan yang baru dan menemukan solusi untuk permasalahan tersebut, (b) peserta didik lebih aktif, baik secara fisik dan mental dalam membangun pengetahuan dan informasi, dan(c) menekankan pada kerjasama dan lingkungan sosial belajar, serta pembelajaran selalu dikaitkan dengan konteks yang dihadapi peserta didik dalam kehidupan sehari-hari.

Secara operasional, langkah-langkah yang dapat diterapkan dalam model Codacc Learning adalah The Power of Two, Information Search, Jigsaw, Debate Active, Listening Team, Simulasi Berpasangan, Modelling the way, Gallery Walk, Card Sort, Group to group exchange, Small group Discussion, Billboard ranking, True or False, dan lain sebagainya. 


\section{DAFTAR PUSTAKA}

Anis Ma'tsumah, L., 2014. Pengaruh Model Connac Learning dan Pengelolaan Kelas Terhadap Minat dan Hasil Belajar Kognitif Pendidikan Agama Islam, Disertasi. Pascasarjana UIN WS, Semarang.

Baddock, M., Bucat, R., 2008. Effectiveness of a Classroom Chemistry Demonstration using the Cognitive Conflict Strategy. Int. J. Sci. Educ. 30, 1115-1128. https://doi. org/10.1080/09500690701528824

Beyhan, S., Alci, M., 2011. Extended fuzzy function model with stable learning methods for online system identification. Int. J. Adapt. Control Signal Process. 25, 168-182. https://doi. org/10.1002/acs.1214

Budiningsih, A., 2012. Belajar dan Pembelajaran. Rineka Cipta, Jakarta.

Burleson, W., 2005. Developing creativity, motivation, and self-actualization with learning systems. Int. J. Hum.Comput. Stud. 63, 436-451. https://doi.org/10.1016/j. ijhcs.2005.04.007

Christine, M., 2009. Pedagogi: strategi dan teknik mengajar dengan berkesan. Setia Purna Inves, Bandung.

Dewey, J., 2001. Democracy And Education. The Pennsylvania State University, Pennsylvania.

Hambali, S., 2011. Pengantar Ilmu Falak 1. PascaSarjana IAIN Walisongo, Semarang.

Hamruni, 2009. Strategi dan Model-Model Pembelajaran Aktif Menyenangkan. Fakultas Tarbiyah UIN Sunan Kalijaga, Yogyakarta.

Hernandez-Orallo, J., 2000. Constructive reinforcement learning. Int. J. Intell. Syst. 15, 241-264. https://doi. org/10.1002/(SICI) 1098-111X(200003)15:3<241::AIDINT6>3.0.CO;2-Z

Keyser, M.W., 2000. Active learning and cooperative learning: understanding the difference and using both styles effectively. 
Res. Strateg. 17, 35-44. https://doi.org/10.1016/S07343310(00)00022-7

Komalasari, K., 2011. Pembelajaran Kontekstual Konsep dan Aplikasi. Refika Aditama, Bandung.

Moleong, L.J., 2010. Metodologi Penelitian Kualitatif, (Bandung: Remaja Rosdakarya. Remaja Rosdakarya, Bandung.

Palmer, J.A., 2015. Ide-Ide Berlian 50 Pakar Pendidikan Kontemporer Paling Berpengaruh di Dunia Pendidikan Modern. IRCiSoD, Yogyakarta.

Palmer, S., Holt, D., Bray, S., n.d. The learning outcomes of an online reflective journal in engineering 9.

Purwanto, 2013. Evaluasi Hasil Belajar. Pustaka Pelajar, Yogyakarta.

Rusman, 2014. Model-Model Pembelajaran Mengembangkan Profesionalisme Guru. PT Raja Grafindo Persada, Depok.

Sagala, S., 2012. Konsep dan Makna Pembelajaran untuk Memecahkan Problematika Belajar dan Mengajar. Alfabeta, Bandung.

Sand-Jecklin, K., 2007. The impact of active/cooperative instruction on beginning nursing student learning strategy preference. Nurse Educ. Today 27, 474-480. https://doi.org/10.1016/j. nedt.2006.08.006

Sari, Y.A., 2018. Dinamika Komunikasi Antar Budaya Dalam Harmonisasi Santri Di Pondok Pesantren Darul A'mal Metro. . P 3, 31.

Sibermen, M., 2007. Active Learning, 101 Strategi Pembelajaran Aktif. Yappendis, Yogyakarta.

Sugiono, 2005. Memahami Penelitian Kualitatif. Alfabeta, Bandung. Supraptinah, U., Subanti, S., 2015. Eksperimentasi Model Pembelajaran Discovery Learning , Problem Based Learning, Dan Think-Talk-Write Dengan Pendekatan Saintifik Terhadap Kemampuan Pemecahan Masalah Matematika Ditinjau Dari Kemandirian Belajar Siswa 12.

Suranto, 2009. Konsep Pembelajaran Berbasis Contextual Teaching and Learning. Sindur Press, Semarang. 
Susilawati, W., Suryadi, D., Dahlan, J.A., n.d. The Improvement of Mathematical Spatial Visualization Ability of Student through Cognitive Conflict 12.

Toczek, M.-C., Morge, L., 2009. Effects of evaluativevs. co-constructive interactions on learning in physics. Eur. J. Psychol. Educ. 24, 325-333. https://doi.org/10.1007/BF03174764

Trianto, 2012. Mendesain Model Pembelajaran Inovatif Progresif, KonsepLandasan dan Implementasinya Pada Kurikulum Tingkat Satuan Pendidikan. Kencana, Jakarta.

Wang, Y., Koong, K.S., Sun, J., 2013. E-learning tools for andragogy: a scale model of technology-based active learning. Int. J. Serv. Stand. 8, 214. https://doi.org/10.1504/IJSS.2013.057234

Watson, J., 2000. Constructive Instruction and Learning Difficulties. Support Learn. 15, 134-140. https://doi.org/10.1111/14679604.00162

Yamin, M., 2015. Teori dan Metode Pembelajaran, Konsepsi, Strategi dan Praktik Belajar yang Membangun Karakter. Madani, Malang.

Zhang, H., Small, M., Yang, H., Wang, B., 2010. Adjusting learning motivation to promote cooperation. Phys. Stat. Mech. Its Appl. 389, 4734-4739. https://doi.org/10.1016/j. physa.2010.06.023 